\title{
On the Infiltration of Chinese Traditional Culture in College English Teaching
}

\author{
Fang Liu \\ Xijing University \\ Xi'an, Shaanxi, China \\ Email: 397399097@qq.com
}

\begin{abstract}
This article first elaborates the connotation of Chinese traditional culture penetration in college English teaching, and then focuses on the reasons for infiltration, then analyzes and summarizes the infiltration, methods, problems and countermeasures. It is finally concluded that it is absolutely necessary to infiltrate Chinese traditional culture in college English teaching.
\end{abstract}

Keywords: college English teaching; traditional Chinese culture; Infiltration

\section{THE CONNOTATION OF THE INFILTRATION OF CHINESE TRADITIONAL CULTURE}

To explore the penetration of Chinese traditional culture in college English teaching, we must grasp the connotation of Chinese traditional culture, infiltration, and the infiltration of Chinese traditional culture in college English teaching.

Infiltration is often used to describe something or forces gradually into other aspect. The infiltration of Chinese traditional culture in college English is to put Chinese traditional culture into college English teaching, which means the content of Chinese culture is integrated into college English teaching to enable students to master some descriptions of China.[1] The expression of traditional culture allows students to use English Introduction and disseminate Chinese traditional culture. Of course, it also needs to be pointed out that Chinese traditional culture is profound. There are essences and dross. The traditional Chinese culture infiltrated in College English teaching refers to the typical, excellent, and essential ones.

\section{REASONS FOR THE PENETRATION OF TRADITIONAL CHINESE CULTURE}

To analyze the reasons for infiltrating Chinese traditional culture in college English teaching in previous studies, the emphasis on analysis from the perspective of significance is not enough. It's necessary to analyze its underlying causes and conditions.

\section{A. An Analysis of the Causes of the Infiltration of} Traditional Chinese Culture

1) Traditional Chinese and college English teaching

Language and culture are closely related. "Language is an integral part of culture." "The language does not exist without being separated from the culture." China College English teaching is inseparable from English national culture, but also with Chinese the culture is closely linked. College English teaching cannot be separated from English culture. Nor can it separate from China's cultural and social environment. Chinese traditions Culture also has a migratory effect on college English teaching. The so-called migration is "It means the process of learning and mastering that learners apply the previously acquired knowledge and experience to new knowledge.". Migration includes positive and negative.[2] Chinese traditional culture is a positive migration of English teaching. The language habits of the traditional culture of the country can be properly applied to English teaching to promote Into English learning; negative transfer refers to traditional Chinese culture's negative interference to students in English teaching. As native-born Chinese, they are influenced by Traditional Chinese Culture in the process of learning English. Therefore, we must strive to achieve the positive migration so as to better improve College English learning effects.

2) College English course teaching requirements (hereinafter referred to as "Course Requirements") with traditional Chinese culture Aphasia

The "Course Requirement", which is the main basis for college English teaching, mentions "culture" in seven areas in terms of teaching nature and goals, teaching requirements, and curriculum setting. It also includes "ability to translate articles that introduce Chinese national conditions or culture" as translation capabilities. It shows that the infiltration of Chinese traditional culture in college English teaching is an unprecedented height from the overall perspective of college English teaching throughout the country. [3] To achieve the objectives of the "Course Requirements", it is necessary to infiltrate Chinese traditional culture in college English teaching.

However, the current situation of college English teaching is that college English teaching mostly focuses on books and introduces traditional Chinese cultural with little or no related Western themes. Therefore, it is common for college students to fail to express Chinese traditional culture. That is to say, "students in cross-cultural communication have insufficient understanding of the English interpretation of their own culture and cannot express Chinese culture in proper English, leading to failure or inefficiency in communication, thus causing foreigners to misunderstand Chinese culture. To change the status quo of college students' Chinese traditional culture aphasia, we must infiltrate Chinese traditional culture in teaching.

3) Traditional Chinese culture and college students' cultural quality

Traditional Chinese culture has had a profound influence on people's ideological consciousness, behavior, 
and social and historical development for thousands of years. "In any era, any society can only seek development and progress in the interaction with established traditional culture." College students must also seek development and progress in interaction with traditional culture. As the backbone of the future society, college students shoulder the heavy responsibility of rejuvenating the nation and rebuilding Chinese traditional cultural spirit. Chinese traditional culture provides precious resources for the education of college students' humanistic quality. It is necessary to absorb nutrients from them to improve their own cultural qualities in order to improve their overall quality and thus shoulder the heavy responsibility of spreading and carrying forward Chinese traditional culture.

\section{B. Analysis of the Conditions for the Penetration of Chinese Traditional Culture}

\section{1) Social conditions}

To promote understanding of Chinese language culture among people of all countries, the Chinese government has established Confucius Institutes around the world since 2004 to serve as a cultural exchange organization for promoting Chinese language and spreading Chinese culture. Confucius is a representative figure of Chinese traditional culture. Choosing Confucius as a Chinese international teaching brand is a symbol of the revival of Chinese traditional culture. In addition, in order to cultivate international professionals engaged in Chinese language education and dissemination of Chinese culture at home and abroad in order to improve the ability of promoting Chinese language internationally, from 2007 to now, 82 units have been allowed to develop masters of Chinese in international education, indicating that Chinese culture is striding toward the world. It can be seen that Chinese traditional culture has ushered in an excellent period of great development. This undoubtedly provides an excellent social environment for Chinese cultural penetration in college English teaching.

\section{2) Material economic conditions}

With the social and economic development in China, the penetration of Chinese traditional culture in college English teaching already has all kinds of good material and economic conditions. Foreign publishers, foreign teachers' associations and other large publishers have developed rich Chinese traditional cultural teaching materials (such as college English development textbooks, English translations of classic books, etc.); national and provincial quality courses related to Chinese traditional culture also provide a wealth of excellent products. With the popularity of the Internet, the Internet provides people with a wide variety of online information resources related to Chinese traditional culture, such as text, pictures, audio, video, etc.; the school provides students with a wealth of library books, multimedia, and networking. Hardware and other equipment resources; teachers and students can use the Internet and other modern teaching methods to obtain all kinds of information related to traditional Chinese culture. It can be said that the penetration of Chinese traditional culture in teaching has already had solid material and economic conditions.

\section{Analysis of Meaning}

There are some researches on the significance of Chinese culture in English language teaching and their main viewpoints are: they are conducive to cross-cultural communicative competence and are conducive to improving the comprehensive application of English. [4] They are conducive to deepening domestic and foreign cultures. The understanding helps to improve the ability of cultural identification.

In addition, infiltrating traditional Chinese culture in college English teaching is also conducive to realizing the positive transfer of traditional Chinese culture in college English teaching. It also helps to change the phenomenon of aphasia in traditional Chinese culture and improve the ability of college students to disseminate traditional Chinese culture. It is also beneficial for improving the cultural quality of university students and the entire country.

\section{MEASURES FOR INFILTRATION OF TRADITIONAL CHINESE CULTURE}

To explore measures for infiltrating Chinese traditional culture in college English teaching, it is necessary to analyze its methods, problems encountered and countermeasures.

\section{A. Methods of Chinese Traditional Culture Infiltration}

Researchers have studied many ways of infiltrating Chinese traditional culture. They mainly include: adjusting the content of teaching materials, comparing Chinese and Western cultures, improving the quality of teachers, and carrying out extra-curricular activities, paying attention to the formulation of policies and strengthening relevant Academic research, creating a good social environment and so on. The above methods proposed by the researchers are relatively comprehensive, but some researchers have not discussed some specific problems and countermeasures that may exist in the process of Chinese traditional culture infiltration.

\section{B. Problems encountered in the penetration of Chinese traditional culture and countermeasures}

\section{1) Problems of thought recognition and} countermeasures

Thought is the precursor to understanding. In college English teaching, teachers and students all have more or less ideology that does not attach importance to the penetration of traditional Chinese culture. The status quo of Chinese traditional culture aphasia is exactly proof. Therefore, we must change it step by step. First of all, we must change the teachers' thoughts, who do not attach importance to the penetration of traditional Chinese culture. [5] To achieve the infiltration of traditional Chinese culture, there must be active participation of teachers who are classroom organizers and guides. Second, teachers should guide students to actively participate in the study of traditional Chinese cultural knowledge in college English learning. In teaching, students often do not understand why they should learn Chinese traditional 
culture in English classes. Therefore, teachers are required to patiently guide students to understand the importance and significance of infiltrating Chinese traditional culture in the English class. Only the majority of teachers and students recognize the importance of infiltrating Chinese traditional culture in the teaching of college English and can receive good results.

\section{2) Material preparation lesson problems and countermeasures}

In the face of profound Chinese traditional culture coexisting, what materials should be selected in the college English class should be related to the effectiveness of teaching and its success or failure. Therefore, we can adopt a method of selecting the preferred ones, that is, to select typical and excellent Chinese traditional cultural materials that are closely related to students, so that students are also willing to accept and actively participate, which is conducive to the formation of good teaching results. The problem of lack of uniform materials is prominent in the preparation of lessons. With a large amount of preparation, teachers need to prepare materials for the students and prepare relevant English materials. They must also prepare lessons for possible problems in the students' classrooms, and prepare lessons for those words that have English translation and that do not have English translation. Therefore, the power of individuals alone is difficult to achieve. The feasible way is to form a teaching group and carry out collective lesson preparation so that the teaching team members can take full advantage of their special skills. Only in this way can courses be prepared as fully as possible.

3) Problems in Course Cohesion and Countermeasures

The problem of course cohesion includes: the problem of connecting with the textbook knowledge and the real life. The connection with textbook knowledge requires teachers to use the college English textbooks to infiltrate traditional Chinese culture and strive to achieve a reasonable combination of textbooks and extra-curricular materials. For example, when learning new American English textbooks in New Horizons, Americans who have a strong sense of time, honesty, how to make a good impression, and say hello and apologize, it's necessary to compare western culture with Chinese traditional culture. The convergence with real life requires teachers to introduce traditional Chinese culture with their own experiences. Students can interact with teachers through their own experiences. For example, to introduce Valentine's Day can be combined with China's Tanabata, introduced Christmas can be compared to introduce the Chinese New Year, which is conducive to achieving better teaching results.

\section{REFERENCES:}

[1] Ying TAO. Study on the Development Model of Primary and Secondary School Teachers under the Background of New Curriculum Reform [J]. Journal of Hebei Normal University (Education Science Edition), 2009, (12): 70.

[2] Jianping ZHOU. Understanding and Thinking on School-based Training [J]. Educational Exploration, 2002, (4): 32.

[3] Lixin YAO. Teacher stress management [M]. Hangzhou: Zhejiang University Press, 2005.
[4] Xi WANG. English teacher action research [M]. Beijing: Foreign Language Teaching and Research Press, 2002:230.

[5] Maslach C, Jackson S E. The measurement of experienced burnout. Journal of Occupational Behavior, 1981, (2):99-113. 